www.jmscr.igmpublication.org

Impact Factor 5.84

Index Copernicus Value: 83.27

ISSN (e)-2347-176x ISSN (p) 2455-0450

crossref DOI: _https://dx.doi.org/10.18535/jmscr/v5i7.112

Journal Of Medical Science And Clinical Research

IGM Publication

An official Publication of IGM Publication

\title{
A Study on Microcytic Hypochromic Anaemia with the Help of Parameters: CBC with RBC Indices, Biochemical Markers (Iron Profile) and HPLC - A Hospital Based Observational Study
}

\author{
Authors \\ Dr Sunanda Mondal MD ${ }^{1}$, Dr Gopinath Barui MD², Dr Rupam Karmakar MD ${ }^{3}$ \\ ${ }^{1}$ Senior Resident, R G Kar Medical College, Kolkata \\ ${ }^{2}$ Associate Professor, R G Kar Medical College, Kolkata \\ ${ }^{3}$ Professor, Burdwan Medical College, Burdwan \\ Corresponding Author \\ Dr Gopinath Barui \\ Associate Professor, Department of Pathology, R G Kar Medical College, Kolkata \\ Add;- Flat no-C-5/6, Payamanti Cooperative Housing Society, E K T P , PHASE-I Kolkata -700107 \\ Mobile no-9831250951, Email-gnbarui@gmail.com
}

\begin{abstract}
Background of the study- Anaemia is a common problem woridwide, specially in the developing countries and amidst rural population. Microcytic hypochromic anemia is more prevalent clinicopathological subtype which is found in our day to day practice. In our study we have a humble effort to find out the major etiological factors behind this microcytic hypochromic anemia in a hospital based study on rural and urban Bengal.

Aims and Objective- To find out the major etiological factor behind the microcytic hypochromic anemia with the help of complete blood count with RBC indices, iron profile (serum iron, serum ferritine and total iron binding capacity) and HPLC

Materials and Method- This hospital based cross sectional observational study was done on newly diagnosed cases anaemia in all age group except neonate. In each case CBC with RBC indices and RDW was measured by Automated cell counter ( SYSMEX KX21), serum iron profile was done by ELISA mehod and HPLC was done in BIORAD VARIANT-II. All results were analysed.

Results and Analysis- Total 150 cases of microcytic hypochromic anemia were selected on the basis of above parameters and grouped as Group-1 ( iron deficiency anemia-IDA) cases 90 (60\%), Group-2 ( anaemia on chronic disease-ACD ) cases 31 ( 21\%) and Group-3 (thalassaemia) cases 29 (19\%). Distribution of iron deficiency anaemia (IDA) predominantly (84\%) was seen in female and in reproductive age (31-40 yrs) and in pre or post menopausal women (41-50 yrs). In Group-2 most of the cases of ACD was found in the elderiy age group who were suffering from various type of chronic illness. These age groups are mainly above 50 yrs and male predominant (74\%). In Group-3, thalassemia group majority (55\%) of the cases were from male children and found in age group of. 6-10 yrs .

Conclusion- Iron deficiency anemia comprises the major cause of microcytic hypochromic anemia in a study of both rural and urban population of Bengal.
\end{abstract}

Keywords: Microcytic Hypochromic anaemia, CBC, iron profile, HPLC. 


\section{INTRODUCTION}

Anemiais a common disorder in third world developing country. Microcytic hypochromic anaemia is not an uncommon occurrence rather it is widely prevalent in adults and children of rural population. It has got a myriad of manifestations with varied aetiologies. An cross sectional observational study has been done to the patients who are suffering from microcytic hypochromic anaemia attending at medicine and paediatric indoor department of R G Kar medical college \& hospital with the help of following parameters like $\quad \mathrm{RBC}$ indices (MCV, MCH, MCHC), Red Cell Distribution Width(RDW),Serum IRON, serum FERRITIN, Total Iron Binding Capacity (TIBC), and High Performance Liquid Chromatography (HPLC).

\section{AIMS AND OBJECTIVE}

This study aims at determining the spectrum of frequencies, common clinical presentations and etiologies of microcytic hypochromic anaemia presenting to inpatient departments of R G Kar Medical College and hospital.

a) To find out the association of microcytic hypo chromic anaemia with $\mathrm{RBC}$ indices like MCV, $\mathrm{MCH}$ and $\mathrm{MCHC}, \mathrm{RDW}$, Serum Ferritin, Serum iron, TIBC and High Performance Liquid Chromatography (HPLC).

b) To measure severity of the disease so that we can easily treat those patient who are suffering from anaemia.

c) To find out etiological factors related to microcytic hypochromic anaemia.

\section{STUDY SETTINGS}

This observational study has been carried out in the department of Pathology of R G Kar medical college \& hospital in association with Department of biochemistry. Total study period is one year from April 2015 to march 2016. Study population included Patients attending at medicine and paediatric indoor of at $\mathrm{R} \mathrm{G}$ Kar medical college and hospital. Total 150 cases were included in the study.

All newly diagnosed cases of anaemia as well as anaemia with any type of following diseased conditions like Malignancy, Kidney disease, Diabetes mellitus, Hypertension collagen vascular diseases like SLE, rheumatoid arthritisetc were included in the study in the category anaemia of chronic disease (ACD). Neonates, anemia due to bleeding and coagulation disorder, known cases of macrocytic anemia, patients on chemotherapeutic agents and steroid therapy were excluded from study.

Cases, as per inclusion and exclusion criteria, were selected by simple random sampling who are anaemic, from the patients attending in the indoor of paediatrics and medicine departments. After approval from institutional ethical committee and informed written consent from the patient/patients guardian the study was initiated.

\section{MATERIALS AND METHOD PARAMETERS STUDIED}

a) Clinical history and clinical features of the patients were noted.

b) Complete haemogram and $\mathrm{RBC}$ indices was noted by automated cell counter, peripheral blood smear were performed and analyzed.

c) Serum Iron level, Total Iron Binding capacity (TIBC) and Serum ferritin level measured by ELISA method.

d) HPLC was done in cases where PBS, complete haemogram and iron profile was suggestive of haemoglobinopathies.

\section{RESULT AND ANALYSIS}

Total 150 cases of microcytic hypochromicanemia were selected on the basis of results of above mentioned parameters and as per inclusion and exclusion criteria. Broadly they were grouped into Group-1, Group-2 and Group-3.

Distribution of microcytic hypochromic anaemia in different group on the basis of mean $\mathrm{HB} \%$ and iron profile. 


\begin{tabular}{|l|c|c|c|c|c|c|c|}
\hline Group & Types of anaemia & $\begin{array}{c}\text { No of } \\
\text { cases }\end{array}$ & percentage & $\begin{array}{c}\text { Mean } \\
\mathrm{HB} \% \\
\mathrm{Gm} / \mathrm{dl}\end{array}$ & $\begin{array}{c}\text { Mean } \\
\text { serum } \\
\text { iron } \mu \mathrm{g} / \mathrm{dl}\end{array}$ & $\begin{array}{c}\text { Mean } \\
\text { TIBC } \\
\mu \mathrm{g} / \mathrm{dl}\end{array}$ & $\begin{array}{c}\text { Mean serum } \\
\text { ferritin } \mu \mathrm{g} / \mathrm{L}\end{array}$ \\
\hline GROUP 1 & $\begin{array}{c}\text { IRON DEFICIENCY } \\
\text { ANAEMIA }\end{array}$ & 90 & $60 \%$ & 6.872 & 39.37 & 1214.30 & 16.49 \\
\hline GROUP 2 & $\begin{array}{c}\text { ANAEMIAF CHRONIC } \\
\text { DISEASE }\end{array}$ & 31 & $21 \%$ & 8.994 & 80.93 & 312.09 & 677.45 \\
\hline GROUP 3 & THALASSAEMIA & 29 & $19 \%$ & 5.659 & 433.07 & 298.48 & 1323.4 \\
\hline & TOTAL CASE & 150 & $100 \%$ & 7.076 & 184.4 & 608.29 & 672.46 \\
\hline
\end{tabular}

Table-1:- Distribution of microcytic hypochromic anaemia in different groups. Most (60\%) of microcytic hypochromic anaemia occurs is Iron deficiency anaemia.

GROUP-1-Distribution of iron deficiency anaemia according to sex

\begin{tabular}{|l|c|c|}
\hline Sex & No Of Cases & Percentage \\
\hline Male & 14 & $16 \%$ \\
\hline Female & 76 & $84 \%$ \\
\hline Total & 90 & $100 \%$ \\
\hline
\end{tabular}

Table -2: Distribution of iron deficiency anaemia according to sex. Iron deficiency anaemia (IDA) predominantly (84\%) seen in female.

GROUP-1:- Distribution of iron deficiency anaemia in different age group

\begin{tabular}{|l|c|c|}
\hline \multicolumn{1}{|c|}{ AGE } & CASES & PERCENTAGE \\
\hline $0-10 \mathrm{Yrs}$ & 0 & $0 \%$ \\
\hline $11-20 \mathrm{Yrs}$ & 7 & $8 \%$ \\
\hline $21-30 \mathrm{Yrs}$ & 11 & $13 \%$ \\
\hline $31-40 \mathrm{Yrs}$ & 17 & $20 \%$ \\
\hline $41-50 \mathrm{Yrs}$ & 23 & $26 \%$ \\
\hline $51-60 \mathrm{Yrs}$ & 13 & $15 \%$ \\
\hline $61-70 \mathrm{Yrs}$ & 8 & $9 \%$ \\
\hline $71-80 \mathrm{Yrs}$ & 8 & $9 \%$ \\
\hline & TOTAL CASE $=90$ & $100 \%$ \\
\hline
\end{tabular}

Table -3-Distribution of iron deficiency anaemia (IDA) according to different age group. Majority of the IDA is seen in reproductive age (31-40 yrs) and in pre or post menopausal women (41-50 yrs).

GROUP- 2-Anaemia Of Chronic Disease (ACD) Distribution of anaemia of chronic disease according to sex

\begin{tabular}{|l|r|r|}
\hline Sex & No Of Cases & Percentage \\
\hline Male & 23 & $74 \%$ \\
\hline Female & 9 & $26 \%$ \\
\hline Total Case & 31 & 100 \\
\hline
\end{tabular}

Table - 4: Distribution of anaemia of chronic disease according to sex. $74 \%$ of males are suffering from ACD.
GROUP- 2-Distribution Anaemia of Chronic Disease According to Age

\begin{tabular}{|l|c|}
\hline AGE & NO OF CASES \\
\hline $0-10$ YRS & 0 \\
\hline $11-20$ YRS & 1 \\
\hline $21-30$ YRS & 3 \\
\hline $31-40$ YRS & 3 \\
\hline $41-50$ YRS & 4 \\
\hline $51-60$ YRS & 7 \\
\hline $61-70$ YRS & 7 \\
\hline $71-80$ YRS & 5 \\
\hline $81-90$ YRS & 1 \\
\hline & Total case $=31$ \\
\hline
\end{tabular}

Table -5:- Most of the cases of ACD are occurred in the elder age group who are suffering from various type of illness. These age groups are mainly above 50 yrs.

GROUP- 3- Thalassaemia

GROUP-3-Distribution According to Sex (Male and Female)

\begin{tabular}{|l|c|c|}
\hline SEX & NO OF CASES & PERCENTAGE \\
\hline MALE & 16 & $55 \%$ \\
\hline FEMALE & 13 & $45 \%$ \\
\hline TOTAL CASE & 29 & $100 \%$ \\
\hline
\end{tabular}

Table-6- Majority (55\%) of the cases were from male children

GROUP-3-Distribution According To Age

\begin{tabular}{|l|c|c|}
\hline AGE & No of cases & PERCENTAGE \\
\hline $1-5$ yrs & 8 & $28 \%$ \\
\hline $6-10 \mathrm{yrs}$ & 21 & $72 \%$ \\
\hline TOTAL CASE & 29 & $100 \%$ \\
\hline
\end{tabular}

Table - 7- Majority of cases have occurred in 6$10 \mathrm{yrs}$ of age group 


\section{DISCUSSION}

Out of the 150 samples investigated in our study, Iron Deficiency Anaemia (IDA) is found in 60\% of all cases, $21 \%$ is of Anaemia of Chronic Disease (ACD) and rest $19 \%$ is Thalassaemia. These three types are divided into GROUP 1, GROUP 2, and GROUP 3 respectively (Table 1). In our studyon the basis of gender we divided GROUP 1 (IDA) microcytic hypochromic anaemia into male and female ratio. There it has been found that female is much more predominant in comparison to male. About 76 cases $(84 \%)$ out of 90 cases found to be iron deficiency anaemia (IDA) (Table 2)

In 2009 august in a study in GUJRAT where Patel $S$ et al selected 100 anaemic patients consecutively from shree Krishna hospital, after getting detailed history and clinical examination. ${ }^{[1]}$ In their study they found 40 patients were diagnosed as Iron deficiency anaemia. Females were affected more than male. There were two peaks in age groups 21-30yrs and 31-50yrs respectively and most of the patients were found to have moderate iron deficiency (53\%).

In our study we have distributed the Iron Deficiency Anaemia (IDA) according to age of the patients, and we have observed that most of this group of anaemia is predisposing at the two peaks of age groups 31-40yrs and 41-60 yrs respectively. In reproductive age (31-40) group there is loss of blood during menstruation and in elderly females (41-60) postmenopausal bleeding is an important cause of anaemia. (Table-3)

The Anshu Sharma et al carried out a study at an urban primary health institution in Delhi, to assess feasibility of screening all pregnant women attending antenatal clinic for anaemia. ${ }^{[2]} \mathrm{A}$ total of 3698 women were screened during the study. Of these $10(0.3 \%)$ had $\mathrm{Hb} 11 \mathrm{~g} / \mathrm{dl}$. Data from the study also showed that even in a maternity centre located in relatively prosperous south Delhi area, the prevalence of anaemia was quite high and moderate anaemia in pregnancy continues to be a major problem in India and parenteral iron therapy remains the optimal mode of management of moderate anaemia in mid trimester. ${ }^{[3,4]}$

Study conducted by Asia Taha, et al ${ }^{[5]}$ in 2014 had shown the prevalence of iron deficiency anemia in reproductive age women, and their relation tovariables such as age, marital status, education with those attending obstetrics and gynecology outpatient of King Faisal University Health Centre in Al-Ahsa in eastern region of Kingdom of Saudi Arabia. This study was conducted for the period of 6 month. They found $54.8 \%$ of respondents were haemoglobin deficient while $77.4 \%$ were found to have low Hct. In $87.1 \%$ of the respondents, transferrin saturation was found to be abnormal. They concluded that iron deficiency anemia isquite prevalent in the university community especially among pregnant women. Thus iron deficiency anemia during pregancy in well-educated set up needs more attention by the concerned authorities.

All these study closely correlates with our study where iron deficiency anaemia is predisposing over to the pregnant women along reproductive age group. Our study comprising almost $50 \%$ of reproductive age of total IDA who are suffering from nutrition deficiency (Table-3).

In a recent study conducted in rural population of Patiala, one of the major city of Punjab,Kaur and Kaur $^{[6]}$ observed that $98 \%$ of female and $56 \%$ of male subjects were anaemic. It was further suggested that poor nutrition profile of the women is positively correlated with haemoglobin level among them.

Similarly, Kaur and $\operatorname{Kochar}^{[7]}$ reported $91.3 \%$ of rural and $86 \%$ of urban women of Haryana Jat community as anaemic showing not only high prevalence among rural population but also reported higher prevalence of anaemia among older women (97\% rural, $90 \%$ urban) compared to middle-aged women ( $88.5 \%$ rural, $84 \%$ urban). It may be that the dietary intake of most of the middle aged women (40-59 years) is less than the recommended value. It may be that they are less educated and are deprived of proper diet due to 
male biased societies in rural areas. They do more physical work and need a well balanced diet.

Globally, Most of the anaemia's are due to inadequate supply of nutrients like iron, folic acid and vitamin B12, proteins, amino acids, vitamins A, C, and other vitamins of B-complex group i.e., niacin and pantothenic acid are also involved in the maintenance of haemoglobin level.

Study by J.B.Sharma, et $\mathrm{al}^{[8]}$ has also shown that Worminfestation $^{[12]}$ prevalence of amebiasis and giardiasis is around $40 \%$ and increased iron loss due to hookworm infestations, schistosomiasis, chronic malaria, excessive sweating and blood loss from the gut due to haemorrhoids are important causes of anemia in pregnancy

All the above study closely corroborates with our study as most of the female patients studied are deprived from lack of proper diet like iron, vitamin $\mathrm{B}_{12}$, vitamin $\mathrm{B}$-complex etc as well as poor hygienic status particularly in family of rural area are responsible for iron deficiency anemia.

The $2^{\text {nd }}$ most common group of microcytic hypochromic anaemia is anaemia of chronic disease (GROUP 2) has been distributed according to sex. There we observed majority $(76 \%)$ of the anaemic patients are in male in comparison to female (24\%). In ACD male suffers from various type of chronic disease like viral, bacterial, parasitic fungal infections. (Table-4)

Anaemia of Chronic disease has been distributed according to different age group. After distribution, it is seen that most of the patients who are suffering from anaemia of chronic disease belong to the age group of two peaks 41-50yrs and 51-60 yrs .(Table-5)

M.D Joseph M et, al. ${ }^{[9]}$ conducted over a series of consecutive, unselected, anaemic patients admitted to a county hospital. In this study all patients admitted to the medicine ward service of a county hospital, were screened for anemia. The patients were divided into three groups on the basis of serum values indicating iron distribution: iron deficiency (serum ferritin less than 10 $\mathrm{ng} / \mathrm{mL}$ ), ACD (serum iron less than $60 \mathrm{ng} / \mathrm{dL}$ and serum ferritin more than $50 \mathrm{ng} / \mathrm{mL}$ ), and all others
(NON-ACD). They found 90 patients with ACD were compared with 75 patients with NON-ACD. The anemia in ACD patients were more severe than most authors describe. The level of saturation of serum iron binding capacity was quite low in ACD (mean 15\%) and was normal in NON-ACD (mean 31\%). Renal insufficiency was the major diagnosis in $16 \%$, and the principal diagnosis in $24 \%$ was a disease not commonly considered to be associated with ACD. In NON-ACD patients, the principal diagnosis was an infectious, inflammatory, or neoplastic disease in $55 \%$, renal insufficiency in $9 \%$, and another disease in $36 \%$.

This study does not corroborate totally with our study as in our study it was found those patients who are suffering from chronic disease, have low level of serum iron that is $<100 \mu \mathrm{g} / \mathrm{dl}$ but it is not less than $50 \mu \mathrm{g} / \mathrm{dl}$ as it is frequently found in cases of iron deficiency anaemia. The serum ferritin level increases to more than $350 \mu \mathrm{g} / \mathrm{l}$ and iron binding capacity also remains normal or increases in few cases in contrast to above study which shows mean serum iron binding capacity (TIBC) is very low ( mean $15 \%$ ).

All thalassaemia patients were included in the GROUP 3 of microcytic hypochromic anaemia. Total numbers of patients were 29 and they all have been divided according to sex. Male children patients were the leading in this group $(55 \%)$ and rest are female children (45\%).(Table-6)

This group has been studied according to the different age distribution. One group is 1-5 yrs and another group is 6-10 yrs. The peak age of thalassaemia was up to $10 \mathrm{yrs}$. After distribution it is been seen most $(55 \%)$ of the thalassaemic children's were at the age group between 6-10 yrs. Most of the thalassaemic children were seen suffering from microcytosis and hypochromia in red blood cell.(Table-7)

Those children who are of 6-10 yrs of age were found to more severe anaemic and they are on regular blood transfusion. On HPLC, they were seen to have very high percentage of $\mathrm{HbF}$ in the blood and they are supposed to be $\beta$-thalassaemia major group and those child below 5 yrs of age 
have lower level of $\mathrm{HbF}$ than major group.This group comprising $\beta$-thalassaemia trait mainly.

A study was conducted by Dr Fakher Rahim et al ${ }^{[10]}$ in Iran on total of 340 subjects from southwest part of Iran in the Research Centre of Thalassaemia and Haemoglobinopathies (RCTH), Iran. Genotyping for known $\alpha$ - and $\beta$-gene mutations was done with gap-PCR and ARMS.

Out of the total 340 individuals, 325 individuals were evaluated to have microcytic hypochromic anemia based on initial haematological parameters such as $\mathrm{MCV}<80 \mathrm{fL}$ and $\mathrm{MCH}<27 \mathrm{pg}$. The Only, there was a significant difference between betathalassaemia trait and beta-thalassaemia major with regard to $\mathrm{MCV}$ and $\mathrm{MCH}$ indices, and also $\mathrm{MCH}$ index between beta-thalassaemia trait and $\mathrm{Hb}$ variants.

\section{CONCLUSION}

Whole study that was conducted shows Irondeficiency anaemia (IDA) is the most common causes of microcytic hypochromic anaemia followed by anaemia of chronic disease. Thalassaemia also comprising a significant role in microcytic hypochromic anaemia in children. Nutritional deficiency especially iron and folic acid is a common health problem in rural women and young children of India. The anaemia prevention and control strategies have focused on correcting this deficiency by routine iron supplementation along with folic acid and vitamin supply to the adolescent and reproductive age group to overcome from such major illness.

People suffering from chronic illness, comprised a major group following nutritional deficiency and anaemia of chronic diseases can be avoided to some extent by continuous and uninterrupted adoption of anti-tuberculosis programme in third world country like India. In thalassaemia prevalent developing countries, carrier screening programs is successful in increasing the awareness about thalassaemia among general population. The study suffers from following limitations -

1) The sample size is not large one.
2) This is a hospital based study. It could not represent the whole population, specially the rural population of Eastern India.

3) There was no control in our study.

4) Sideroblastic anaemia, another important cause of microcytic anaemia not included in our study as it needed bone marrow aspiration for confirmation and it is an invasive procedure as well as difficult to perform in a large population of study group.

\section{REFERENCE}

1. Patel S, Shah M, Patel J, Kumar N. Iron deficiency anaemia in moderate to severe anaemic patients. Gujarat Medical Journal.2009; vol 64 (2).

2. Sharma A, Patnaik R, Garg S, Prema Ramachandran. Detection \& management of anaemia in pregnancy in an urban primary health care institution. Indian $\mathbf{J}$ Medical Res. 2

3. Planning Commission. Tenth Five-Year Plan.Sectoral Policies and Programmes. Nutrition. Government of India. New Delhi. 2003-2007.

4. Raman L, Menon MK, Devi PK, Rao KB. Anaemia in pregnancy. Postgraduate obstetrics and gynaecology. 1986; 3rd edition: $p$ 55-62. Hyderabad: Orient Longmans. 008 Jul; 128(1):45-51.

5. Taha A, Azhar S, Lone T, Murtaza G, Ali Khan S, Mumtaz A. Iron Deficiency Anaemia in Reproductive Age Women Attending Obstetrics and Gynecology Outpatient of University Health Centre in Al-Ahsa, Saudi Arabia. 2014; 11(2): 339-342

6. IP Kaur; S Kaur, Journal of Exercise Science and Physiotherapy.2011;7(1):11 18.

7. MKaur, GK Kochar. Mal J Nutr.2009; 15(2):175 - 184 .

8. Sharma JB, Arora BS, Kumar S, Goel S, Dhamija A. Helminth and protozoal 
intestinal infection : an important cause for anemia in pregnant women in Delhi, India, J Obstet Gynaecol Ind. 2000; 51(6):58-61

9. M.D. Joseph $M$ et,al The anemia of chronic disease: Spectrum of associated diseases in a series of unselected hospitalized patients. The American Journal of Medicine. December $1989 ; 87$, (6): 638-644

10. Fakher Rahim. Microcytic hypochromic anemia patients with thalassaemia: genotyping approach. Indian J Med Sci. 2009 Mar; 63(3):101-8. 